\title{
Sticks and Stones Can Break My Name: Nondefamatory Negligent Injury to Reputation
}

\author{
Kate Silbaugh $\dagger$
}

If a reputation is injured, does it matter whether defamation is the cause? Injury to reputation differs from other items of damage a plaintiff enumerates. Tradition links it to particular tortious conduct-defamation-on the part of a defendant. ${ }^{1}$ This Comment examines ordinary negligent conduct as an alternative ground for recovery for injury to reputation.

Recently, a number of plaintiffs have tried to recover for injury to their reputations from tortious conduct that is not defamatory. Typically, an accident injures a plaintiff's reputation when the plaintiff did not cause the accident but it looks like the plaintiff's fault. If a court finds that a defendant behaved negligently, the court must then decide whether to allow recovery for the resulting injury to a reputation given that the defendant's conduct was not defamatory.

Taken as a whole, the claim of these plaintiffs is that injury to reputation is conceptually distinct from defamatory conduct and the highly-developed tort of defamation. This Comment describes the approaches courts have taken to negligence claims for injury to reputation. It then proposes a test for courts faced with an attempt to recover reputational damage claims brought on a negligence theory. ${ }^{2}$

Some courts have held that all claims for harm to reputation necessarily sound in defamation. Other courts have rejected the idea that defamation preempts all other grounds for recovery. These courts differ in their estimation of when reputation damages are recoverable outside of the tort of defamation. Section I provides an overview of the relevant defamation doctrine. Section II

\footnotetext{
† B.A. 1985, Amherst College; J.D. Candidate 1992, The University of Chicago.

1 A few intentional torts closely related to defamation, such as malicious prosecution and malicious arrest, can also lead to recovery for injury to reputation.

${ }^{2}$ For an examination of reputational damages resulting from breach of contract, see Note, Recovery in Contract for Damage to Reputation: Redgrave v. Boston Symphony Orchestra, Inc., 63 St John's L Rev 110 (1988).
} 
introduces the recent cases. Section III argues that defamation should be the exclusive remedy for plaintiffs who allege reputational injury where a communication is present. Section IV concludes that negligence actions not preempted by defamation should be allowed if both the specific plaintiff and the specific harm were foreseeable to the defendant.

\section{A Brief Overview of Defamation Law}

This Section offers an examination of the relevant defamation doctrine. Because defamation is rooted in the common law rather than in statutes, its definition is imprecise. It is a somewhat confused and illogical field, ${ }^{3}$ and appealing to the principles underlying it provides only partial guidance for these new cases.

\section{A. Original Ideas About Reputation}

In the status society of England during the Middle Ages in which defamation law developed, an assault on a person's reputation was considered an assault on the entire community. ${ }^{4}$ It affronted important status relationships and threatened positions held by everyone. The legal sanction was aimed at the conduct of the defendant who had transgressed the system. ${ }^{5}$ Although the plaintiff could seek to vindicate his personal reputation, the stakes for society were equally important.

In the transition to a market economy, the common understanding of the interest in reputation changed from honor and status to property. Reputation in a market world is an asset developed by the individual, and susceptible to damage like other personal property. ${ }^{6}$ Changes in defamation doctrine have reflected this shift. ${ }^{7}$ The present attempt to sever reputation from tradi-

\footnotetext{
${ }^{3}$ See Van Vechten Veeder, The History and Theory of the Law of Defamation, 3 Colum L Rev 546, 547-48 (1903); Frederick Pollock, The Law of Torts 242-43 (Stevens and Sons, 13th ed 1929); Robert C. Post, The Social Foundations of Defamation Law: Reputation and the Constitution, 74 Cal L Rev 691, 691 (1986); W. Page Keeton, et al, eds, Prosser and Keeton on the Law of Torts $\$ 111$ at 771 (West, 5th ed 1984); James C. Courtney, Absurdities of the Law of Slander and Libel, 36 Am L Rev 552, 553 (1902).

- Post, 74 Cal L Rev at 699-707 (cited in note 3); Robert C. Post, The Social Foundations of Privacy: Community and Self in the Common Law Tort, 77 Cal L Rev 957, 962-63 (1989).

- Post, $74 \mathrm{Cal} \mathrm{L} \mathrm{Rev} \mathrm{at} \mathrm{702-03} \mathrm{(cited} \mathrm{in} \mathrm{note} \mathrm{3);} \mathrm{Peter} \mathrm{Meijas} \mathrm{Tiersma,} \mathrm{The} \mathrm{Language}$ of Defamation, 66 Tex L Rev 303, 314 (1987).

- See Post, $74 \mathrm{Cal} \mathrm{L} \mathrm{Rev}$ at 693-99 (cited in note 3).

${ }^{7}$ For example, the dropping of the actual malice requirement and the development of strict liability both reflect a shift in focus from the defendant's culpable conduct to the plaintiff's injury.
} 
tional causes of action follows naturally the shift from the community condemnation of conduct disruptive of status to an individual property interest in reputation. Although history cannot resolve the current doctrinal questions, it is the backdrop against which these cases are brought.

\section{B. Current Defamation Doctrine}

According to the Restatement (Second) of the Law of Torts, four elements must be present to create liability for defamation: (a) a false and defamatory statement concerning another; (b) an unprivileged communication to a third party; ${ }^{8}$ (c) fault amounting at least to negligence; and (d) certain types of harm. ${ }^{9}$ The communication element plays a key role in the negligence cases. The note accompanying the Restatement says "communication is used to denote the fact that one person has brought an idea to the perception of another." 10

\section{Defamation May Be an Incomplete Remedy}

As noted above, communication is a required element of a defamation action. Sometimes, however, a defendant's negligent conduct does not itself constitute the communication of an idea, yet that conduct may still injure the plaintiff's reputation. In this respect, defamation is an inadequate remedy for some plaintiffs.

Some of the cases examined below lack the communication element of defamation entirely.11 Other cases have a communication element, but the plaintiff chooses to focus on an aspect of the defendant's conduct that is not communicative. ${ }^{12}$ Plaintiffs usually make this choice for strategic reasons, such as avoiding a statute of limitations on defamation actions.

${ }^{8}$ Courts have never imposed strict liability for accidental and non-negligent communication of defamatory matter. See Keeton, Prosser and Keeton on Torts at $\S 113$ (cited in note 3).

- Restatement (Second) of Torts § 558 (American Law Institute, 1977). More precisely, the full text of the Restatement describing the harm states the fourth element as "(d) either actionability of the statement irrespective of special harm or the existence of special harm caused by the publication."

${ }^{20}$ Id at $\$ 559$, comment (a).

${ }^{11}$ In a trivial sense, an idea must always be communicated to injure a reputation, since a reputation is a relational interest. See text accompanying note 66 . But for purposes of defamation law, "communication" should be understood as intentional communication by the defendant, regardless of whether the defendant intended the communication to be injurious.

12 See text accompanying notes $42-45$. 
Recovery for different types of damages has proliferated in modern tort law. ${ }^{13}$ Since most jurisdictions now allow recovery for damage to reputation from a few other intentional torts, ${ }^{14}$ the historical limitation to defamation is inconclusive. A small number of recent cases in different jurisdictions have also allowed recovery for damage to reputation in ordinary negligence. These cases, as discussed below, signal a judicial recognition that defamation is an incomplete remedy for injury to reputation.

\section{The Recent Cases Under the Negligence Alternative}

Several recent cases have addressed the issue of reputational damages in an ordinary negligence action. The courts concentrate on slightly different questions and concerns in reaching their differing conclusions.

Below, this Comment describes the cases brought to recover reputational damages on an ordinary negligence theory. It categorizes them by the line of analysis pursued by the court. The cases focus on whether defamation is the exclusive remedy for damages to reputation. Three categories of cases emerge: courts that argue that defamation and injury to reputation are by definition not severable; those that argue that injury to reputation is recoverable only for intentional torts; and those that analyze the presence of a communication as determining whether defamation preempts the field. None analyze whether negligence is an appropriate alternative theory.

\section{A. Defamation as the Only Game in Town}

Two courts have taken the approach that any claim for damage to reputation is necessarily a defamation action. These courts define defamation exclusively by the injury element, not in combination with the communication element.

In Morrison v Nat'l Broadcasting Co., ${ }^{15}$ the defendant television producer induced the plaintiff university professor to participate in a game show. Unbeknownst to the plaintiff, the producer had rigged the game. The plaintiff argued that when the public learned of the hoax, all participants in the game suffered damage

\footnotetext{
${ }^{13}$ See Quinones v United States, 492 F2d 1269, 1278-79 (3d Cir 1974).

14 The Ross and Morrison courts limited the possibilities for recovery to defamation without mention of other related intentional torts. They may have believed those torts were a part of defamation law; the Restatement does not resolve that question explicitly. See note 54.

1819 NY2d 453, 227 NE2d 572, 574 (1967).
} 
to their reputations because the public could not distinguish between those who had participated in the hoax and those who had not. The court dismissed the professor's complaint. In the court's view, any claim for injury to reputation was a defamation claim, and here the statute of limitations on defamation had run. The court acknowledged that it was unusual to tie an item of damage to one sort of conduct: "unlike most torts, defamation is defined in terms of the injury, damage to reputation, and not in terms of the manner in which the injury is accomplished."16

The court in Ross $v$ Gallant, Farrow \& Co. ${ }^{17}$ similarly held that reputation claims necessarily sound in defamation. The defendant, an accounting firm, prepared an audit report that injured the reputation of a union local's business manager by raising the question of improper use of funds by the union official. The business manager sued the firm for negligently performing its investigation and preparing its report. The court rejected the negligence claim because it considered defamation to be the sole remedy for injury to reputation ${ }^{18}$ and rejected the defamation claim because accounting firms have a qualified privilege from defamation. ${ }^{19}$ This case looked more like defamation than Morrison because there was a communication and publication (in the form of the report itself). Thus the court did not face the difficult scenario of a reputational injury claim without the presence of the traditional elements of defamation.

Other courts disagree with these two, holding that, for the purposes of preempting other causes of action, defamation is a particular combination of injury to reputation and the communication of an idea. ${ }^{20}$

\section{B. Recovery for Intentional Torts Only}

Other courts have recognized that plaintiffs may recover for damage to reputation in actions apart from defamation. Two of those, however, did not allow recovery in a negligence action because in their view damage to reputation is recoverable only for intentional torts.

\footnotetext{
16 Id.

1727 Ariz App 89, 551 P2d 79 (1976).

18 $551 \mathrm{P} 2 \mathrm{~d}$ at 82.

19 Id at 81 .

${ }^{20}$ See, for example, Jorgensen $v$ Massachusetts Port Authority, 905 F2d 515, 519-20 (1st Cir 1990); Bulkin v Western Kraft East, Inc., 422 F Supp 437, 443 (E D Pa 1976). See text at notes $37-40,45$.
} 
In Hamilton v Powell, Goldstein, Frazer \& Murphy ${ }^{21}$ a client sued a law firm after being prosecuted and acquitted as a result of following bad advice the firm gave regarding some securities. The client filed a malpractice action based on negligence and breach of duty, alleging that the bad advice leading to the prosecution had caused humiliation, injury to his reputation, and a decreased capacity to earn money. ${ }^{22} \mathrm{He}$ did not, however, allege fraud or intentional wrongdoing. The court held that claims for injury to reputation "are recoverable only in actions alleging intentional or wanton misconduct, for example, libel and slander, malicious prosecution or malicious arrest." 23 The court focused on its view of the intent requirement in defamation doctrine in rejecting the plaintiff's claim.

Similarly, in Greives $v$ Greenwood, ${ }^{24}$ the court rejected a negligence claim for injury to reputation because the tort was not intentional. The plaintiff alleged injury to his reputation as a cattle raiser when the defendant veterinarian negligently inoculated his cattle with a fatal virus. To the Hamilton list of intentional torts for which reputational damages are recoverable, the court added abuse of process and third party contract interference. "These intentional torts afford this remedy because the result is foreseeable. Foreseeability means that which it is objectively reasonable to expect, not merely what might conceivably occur."25 Neither of these two cases discusses why injury to reputation could not be considered a foreseeable result of particular negligent acts.

\section{Cases Allowing Negligence Claims Without Analysis}

In a number of cases, courts have assumed, without analysis, that injury to reputation is a recoverable item of damage from negligent conduct. These courts take the traditional tort law view that a defendant is responsible for the foreseeable consequences of her negligent conduct, including any foreseeable harms to persons' reputations.

In Kennedy $v$ McKesson, ${ }^{26}$ the plaintiff dentist arranged for the defendant repair company to repair his anesthetic machine. The defendant negligently mislabelled dispensers so that nitrous

\footnotetext{
${ }^{21} 167$ Ga App 411, 306 SE2d 340 (1983), affod, 252 Ga 149, 311 SE2d 818 (1984).

${ }^{22} 306$ SE2d at 340 .

${ }^{23} \mathrm{Id}$.

24550 NE2d 334 (Ind App 1990).

${ }^{25}$ Id at 338 (citations omitted).

${ }^{26} 58$ NY2d 500, 448 NE2d 1332 (1983).
} 
oxide flowed from a tube marked "oxygen." The dentist, intending to administer oxygen to a patient, administered nitrous oxide instead, killing the patient. The dentist sued to recover for damage to his reputation caused by the defendant's negligence. The court allowed recovery without discussing the plaintiff's failure to bring a defamation action.

In Oksenholt $v$ Lederle Laboratories, ${ }^{27}$ the court allowed an action in negligence against a drug manufacturer for injury to a physician's reputation after a patient became blind as a result of taking a drug the physician had prescribed. The court did not ask whether damage to reputation is recoverable only for intentional torts. Instead, the court noted that federal regulations require drug manufacturers to warn of the contraindications of their products, and that the defendant had failed to do so. ${ }^{28}$ The court held that under state law foreseeability is assumed where the defendant violates safety regulations. ${ }^{29}$

\section{Analysis of the Communication Element}

Communication is indisputably a required element of a defamation action. Many courts properly focus their attention on that communication requirement: if a communication is present, those courts limit plaintiffs to defamation actions..$^{30}$ Conversely, these courts hold that where there is no communication, a complaint alleging damage to reputation is not constrained by the requirements of a defamation cause of action. ${ }^{31}$ As noted below, these courts disagree about the proper definition of "communication." In addition, some courts allow recovery in negligence where a communication is present, as long as the complaint addresses negligent conduct other than the communication.

1. The definition of communication.

Courts that allow a negligence claim only in the absence of a communication disagree about what constitutes "communication." For example, the court in Jimenez-Nieves $v$ United States, recognized that for defamation to preempt the field the complaint needs more than just damage to reputation-a communication is also

\footnotetext{
27294 Or 213, 656 P2d 293 (1982).

${ }^{28} 656$ P2d at 296.

29 Id at 297.

${ }^{30}$ Jimenez-Nieves $v$ United States, 682 F2d 1, 1 (1st Cir 1982); Jorgensen, 905 F2d at

${ }^{31}$ Jorgensen, $905 \mathrm{~F} 2 \mathrm{~d}$ at 515; Quinones, $492 \mathrm{~F} 2 \mathrm{~d}$ at 1278-79.
} 519-20. 
necessary ${ }^{32}$ The court then said that a communication can be present though it is implicit rather than explicit.

In Jimenez-Nieves, the Social Security Administration made a keypuncher's typographical error in a file, stating that the plaintiff's mother had died a year later than she had. As a result, the SSA told the plaintiff's financial institutions that it was dishonoring his checks. ${ }^{33}$ The plaintiff alleged that the keypuncher's negligent act of entering incorrect data injured his reputation. The outcome of the case turned on whether a communication had occurred. If the SSA communicated a defamatory statement, then the plaintiff's claim would fail because, as a branch of the federal government, the SSA was exempt from defamation actions under the Federal Tort Claims Act. ${ }^{34}$

The court turned to the Restatement's definition of communication. The Restatement interprets "communication" to "denote the fact that one person has brought an idea to the perception of another." 35 The court held that dishonoring the checks implicitly communicated defamatory statements to the plaintiff's bank, employer, and other institutions. The court explained that the claim "resound[s] in the heartland of the tort of defamation: the injury is to reputation; the conduct is the communication of an idea, either implicitly or explicitly." 36 Because the court found a communication, it rejected the plaintiff's negligence claim.

In Jorgensen $v$ Massachusetts Port Authority, the Court took a different approach to analyzing the presence of a "communication" by emphasizing that the defendants themselves must assertively communicate the idea. ${ }^{37}$ In that case, airline pilots whose plane skidded on the runway brought an action against the airport operator, alleging that the operator's negligence in allowing ice to accumulate on the runway caused damage to the pilots' reputations as safe pilots. ${ }^{38}$ The ground crew's negligence had already been established. The only issue remaining was whether the airport should compensate the pilots for their inability to find work after the accident as a result of harm done to their reputations.

The court recognized that recovery for damage to reputation in an ordinary negligence case may be possible, because the ab-

${ }^{32} 682 \mathrm{~F} 2 \mathrm{~d}$ at 1.

${ }^{33}$ Id at 2.

34 28 USC $\S \S 1346(b), 2680$ (1988). See text accompanying notes 64-65.

${ }^{35}$ Restatement (Second) of Torts $\$ 559$, comment a (cited in note 9).

${ }^{36}$ Jimenez-Nieves, 682 F2d at 6 (citations omitted).

${ }^{37}$ 905 F2d at 519-20.

${ }^{38}$ Id at 517. 
sence of a communication takes an injury to reputation out of the field of defamation. The court distinguished Jimenez-Nieves by arguing that in that case, the defendant had implicitly communicated something; here, however, there was not even implicit communication. ${ }^{39}$ Rather, the court held, the defendant caused an accident and it was the accident, rather than the defendant, that communicated the harmful message. ${ }^{40}$ Since no conduct of the defendant's resembled even implicit communication, the negligence claim was possible.

2. Claims allowed despite a communication.

Some courts allow negligence claims to survive in spite of a communication if the complaint addresses other, noncommunicative negligent conduct by the defendant. Often, this allows plaintiffs to circumvent special requirements of a defamation action, such as a statute of limitations, or exemption under the Federal Tort Claims Act. In Quinones $v$ United States, the Third Circuit held that Pennsylvania would recognize a cause of action in negligence for damage to reputation. ${ }^{41}$ The plaintiff, a former federal employee, alleged that the federal government failed to use due care in maintaining his personnel records, resulting in damage to his reputation. ${ }^{42}$ The federal administrative regulations governing maintenance of personnel records contemplated dissemination of information to prospective employers and warned of a risk of injury to an employee's reputation. ${ }^{43}$ The court held that a duty arose to use reasonable care in maintaining the accuracy of the records because the risk of injury was contemplated. According to the court, a claim arising from the breach of this duty is cognizable as an ordinary tort action outside of defamation, although a claim based on breach of the duty to disseminate accurate information is barred under the Federal Tort Claims Act as defamation. ${ }^{44}$ In other words, the decision turned on whether the plaintiff had focused on the communication in framing the complaint, or on the negligent recordkeeping itself.

39 Id at 521 .

10 Of course, the harm to reputation actually arises from people's interpretation of the accident.

$4492 \mathrm{~F} 2 \mathrm{~d}$ at $1276-79$.

12 Id at 1272.

43 Id at 1276-77.

4t Id at 1277-78, 1281. 
The district court in Bulkin v Western Kraft East, Inc., followed the court in Quinones in holding that a claim of negligent recordkeeping is different from a claim focusing on the communication of the resulting defamatory matter. ${ }^{45}$ The court likewise allowed a plaintiff alleging negligent record-keeping to recover because of the way he characterized the complaint.

\section{Resolving the Courts' Concerns}

The first question raised by the cases, and in many cases the only question, is whether the cause of action brought in ordinary negligence is actually a cause of action in defamation that has been mischaracterized. Courts focus most of their attention on the definition of defamation. Even if a court believes the claim is not a mischaracterized cause of action in defamation, this Comment suggests it should still struggle with a second question: whether to allow recovery in ordinary negligence for damage to reputation. Surprisingly, most courts have not concerned themselves with this question. This section proposes resolutions to the issues the courts do address. The next section discusses the question the courts do not address-the proper negligence standard.

This section analyzes and attempts to resolve four concerns of the courts. First, it discusses the argument that defamation is defined as that which injures reputation, such that all claims for injury to reputation must be defamation claims. Second, it discusses the foreseeability concerns evident in a number of the cases and argues that foreseeability should be an important part of a court's analysis. Third, it addresses the concern that plaintiffs suing in negligence can strategically evade requirements of defamation law, such as exemptions or statutes of limitation. Finally, it discusses the views of communication taken by the various courts. It proposes a view of the communication element that preserves the values of defamation law and addresses the evasion concern, while allowing recovery for worthy claims.

\section{A. Reputational Injuries Result From More than Defamation}

In Ross $^{46}$ and Morrison, ${ }^{47}$ the courts argued that defamation was defined by the injury; that is, whenever a plaintiff alleges damage to reputation, her allegations will sound only in defamation. At

\footnotetext{
15422 F Supp at 445.

16551 P2d 79.

47227 NE2d 572.
} 
one time, defamation may have been the only tort to cover damage to reputation. But damage to reputation did not define the entire cause of action-other elements were also essential. It would be anomalous to define the entire cause of action by reference to only one of its elements. Moreover, recovery for different types of injuries has proliferated in modern tort law. ${ }^{48}$ Given this expansion, the fact that courts originally limited recovery for injury to reputation to defamation is not dispositive. ${ }^{49}$

The simplest and perhaps the best reason to conclude that defamation alone does not exhaust the routes to recovery for damage to reputation is that most states allow recovery for a number of other narrowly-defined torts that injure reputation. Specifically, these states allow recovery for injury to reputation for specific intentional torts, such as malicious prosecution, malicious arrest, abuse of process, and third party contract interference. ${ }^{50}$

In addition, the First Circuit recently permitted an entertainer to recover for damage to her reputation from a producer who had broken a contract to allow the entertainer to perform. ${ }^{51}$ The court noted that reputation damages are not ordinarily recoverable in contract actions because such damages are not easily foreseeable by the contracting parties. ${ }^{.2}$ In this case, however, the plaintiff's reputation was at stake because she was a performer whose livelihood rested primarily on her reputation and thus the damage could have been foreseeable. ${ }^{\text {s3 }}$

These cases demonstrate that a plaintiff may recover reputational damages in nondefamation actions-both in tort and in contract. In the face of these established torts, it must be wrong to maintain that defamation preempts any other action. ${ }^{54}$ These dis-

48 Quinones, $492 \mathrm{~F} 2 \mathrm{~d}$ at 1278.

49 Id at 1278-79.

${ }^{30}$ See, for example, Hamilton, 306 SE2d at 344 (noting that reputational damages may be recovered for malicious arrest and malicious prosecution); Greives, $550 \mathrm{NE} 2 \mathrm{~d}$ at 338 (noting abuse of process, malicious prosecution and third party contractual interference); Restatement (Second) of Torts $\S 670$ (a) (cited in note 9) (recovery for damage to reputation allowed in action for malicious prosecution). banc).

s1 Redgrave v Boston Symphony Orchestra, Inc., 855 F2d 888, 892-94 (1st Cir 1988) (en

82 Id at $892-93$.

6s Id at 893-94.

84 Perhaps the courts in Ross and Morrison believed that actions for harm to reputation brought on these alternative intentional tort theories are actually defamation actions. Indeed, the Restatement (Second) of Torts $\$ 670$, comment a (cited in note 9), describing malicious prosecution, notes that " $[t]$ he institution of criminal proceedings necessarily carries with it a defamatory accusation of criminal conduct, and the rules that determine the right to recover for the resulting harm to reputation and distress are similar to those appli- 
crete means of recovery, however, do not in themselves provide justification for allowing recovery for reputational damage on any additional theories, particularly on a theory as far-reaching as ordinary negligence..$^{55}$

\section{B. Resolving the Foreseeability Concern}

Several courts have discussed foreseeability concerns in the negligence context. In Greives $v$ Greenwood and Hamilton $v$ Powell, Goldstein, Frazer \& Murphy, the courts limited the alternative potential causes of action to intentional torts. The Greives court cited foreseeability as its motivating concern.

However, in two other cases, courts explicitly ruled out foreseeability problems. In Oksenholt, the defendant drug company failed to comply with federal regulations requiring drug labeling. ${ }^{.6}$ Under state tort law, foreseeability is presumed when a defendant violates safety regulations. ${ }^{57}$ In Quinones, ${ }^{58}$ a federal administrative regulation governing the maintenance of personnel records contemplated a risk to employees' reputations from improper record-keeping. ${ }^{59}$ The court held that a corresponding duty to protect the reputation comes with foreseeing the potential harm, and allowed the claim in negligence. ${ }^{60}$

Neither the Oksenholt nor the Quinones courts used the clear foreseeability of injury in the cases before them to address the claim that injury to reputation is recoverable only from intentional torts; that is, to repudiate the Greives framework explicitly, but intent was absent in both cases and the courts still correctly found that the injury was foreseeable. As will be argued in Section IV, an exacting foreseeability standard should be required to recover reputational damages in a negligence action. However, Oksenholt and Quinones demonstrate that an intent requirement is not necessary to achieve that foreseeability standard.

cable in actions for defamation." Such statements can be confusing. The malicious prosecution is itself defamatory, but the action is only "similar to" a defamation action, not the same as one.

${ }^{\circ 5}$ See Section IV for an examination of the issues raised by a claim of reputation damages in an ordinary tort of negligence.

${ }^{58}$ See text accompanying notes 27-29.

${ }^{87}$ Oksenholt, 656 P2d at 297.

${ }^{s 8}$ See text accompanying notes $41-44$.

so $492 \mathrm{~F} 2 \mathrm{~d}$ at 1276-77.

bo Id at 1281. 
C. Plaintiffs' Attempts to Avoid the Procedural Requirements of Defamation

Some plaintiffs have characterized their claims outside of defamation to avoid a procedural requirement of defamation law. While courts have not stated explicitly that this evasion troubles them, it does seem to play a role in their desire to limit recovery. This subsection argues that plaintiffs should not be permitted to avoid these procedural requirements if their claims are otherwise complete under defamation.

There are several procedural requirements of defamation law that plaintiffs repeatedly attempt to evade. The Federal Tort Claims Act, which allows plaintiffs to bring suit against the United States where sovereign immunity would otherwise prevent it, exempts from its coverage suits based on either libel or slander. ${ }^{61}$ If the defendant is any department or employee of the United States, the plaintiff will want to separate the injury from the defendant's defamatory conduct in order to evade that exemption. The plaintiffs in both Jimenez-Nieves and Quinones avoided a defamation characterization for this reason. In many states, the statute of limitations is shorter for defamation than for an ordinary negligence action. $^{62}$ In Morrison, the plaintiff brought an action on a negligence theory when the statute of limitations for defamation had expired. In Ross, the defendant enjoyed a qualified immunity from defamation suits because of its status as a CPA firm. The plaintiff would have to have shown actual malice in order to recover, but could only prove negligence.

Not all of these reasons lead to the conclusion that the defamation remedy is inadequate for a plaintiff with a deserving claim. The Federal Tort Claims Act, for example, explicitly prevents defamation actions in order to protect the speech and deliberation of government actors. ${ }^{63}$ All other things being equal, courts should not allow a plaintiff to circumvent this prohibition. Similarly, there

61 The Federal Tort Claims Act, $28 \S 1346$ (b) (1988), provides that a plaintiff may bring a civil suit against the United States. However, certain types of actions are excluded from the statute. In particular, $\S 2680(\mathrm{~h})$ provides that $\S 1346(\mathrm{~b})$ does not apply to libel or slander claims.

6z See, for example, $12 \mathrm{~Pa}$ Stat $\S 32$ (Purdon 1953).

63 The court in Quinones, 492 F2d at 1280, said that the exception to the FTCA for libel and slander exists to protect speech and to provide a risk-free environment for discussion among government officials. If this is the case, actions that do not implicate speech should not be subject to the exception. Therefore, my later suggestion that reputational damages should be recoverable in ordinary negligence only when there is no communication does not run afoul of the intent of the FTCA. 
is no reason to allow a plaintiff to circumvent the statute of limitations laid down by a state in a claim that otherwise would sound in defamation.

Nevertheless, where the injury to reputation does not arise from anything that we can recognize as defamatory conduct, a plaintiff is without a traditional remedy for the injury. For this reason, it is important to distinguish between claims that are attempts to mischaracterize defamation, and claims that are not defamation. The next section argues that, where a communication is present, a plaintiff should bring the claim in defamation, even if the claim ultimately fails because of the ministerial roadblocks discussed above.

\section{The Communication Element}

Courts are most concerned with the issue of a communication. Courts view the communication question in two distinct ways. One group-the "definition" courts-assume that if there is a communication, no other cause of action is allowed. Those courts devote their prime energy to defining "communication." If that term is narrowly defined, they will recognize many nondefamation claims, but if it is broadly defined, they will not. Below, I offer a definition of communication for courts to use when faced with these cases.

In contrast, another group of courts-represented by Quinones-does not assume that where there is a communication, an action can only be in defamation. They argue that a plaintiff may focus on a different aspect of the defendant's conduct, such as the information-gathering process behind the communication. The "definition" courts do not explain the assumption that defamation occupies the entire field of recovery where there is a communication. In other words, they do not address the Quinones view. This section argues that the Jimenez-Nieves view, not the Quinones view, is correct, and provides a rationale for that position.

1. Defining communication.

The "definition" line of cases strives to define communication. Here, the Comment examines the different courts' views and derives a workable definition from them.

a) The Jimenez-Nieves implicit communication view. In Jimenez-Nieves ${ }^{64}$ the court argued that the communication ele-

${ }^{64} 682$ F2d 1. 
ment of defamation can be implicit and not explicit. The court stated that by dishonoring checks, the Social Security Administration implicitly communicated defamatory statements to the plaintiff's bank and employer. ${ }^{65}$ The plaintiff had tried to characterize the tortious conduct as negligent keypunching, not as communication, in an effort to circumvent the federal government's immunity to defamation suits under the FTCA.

Reputation is a relational interest; it is what one person thinks of another, and it requires a social context for its existence. ${ }^{66}$ Thus an idea must always be conveyed in order for a reputation to be affected. The Jimenez-Nieves court's "implicit communication" view effectively extends the definition of communication to encompass anything that could touch a reputation. If we accept that view, the task is only to find the communication of the idea; by definition it can be found.

b) The Jimenez-Nieves court's misreading of the Restatement. The Jimenez-Nieves court relied on the Restatement in defining communication. ${ }^{67}$ However, the court's reading of the Restatement stretches its communication definition. The comment accompanying the Restatement definition of communication says that an activity, such as shadowing someone, can count as a communication if that activity communicates an idea to a third party. ${ }^{68}$ But the use of this example in the Restatement comment is somewhat misleading. It obscures the harder question-what is meant by an "implicit" communication?

The Restatement's example comes from Schultz $v$ Frankfort Marine Accident \& Plate Glass Insurance Co., ${ }^{69}$ where the defendant hired a detective to publicly shadow the plaintiff. The court held that the conduct constituted the communication of an idea. The court emphasized the "public, notorious, and continued character of the surveillance" in deciding that it constituted a public declaration that the plaintiff was suspect and "deserves watching."70 The court concluded that "without taking up the question of secret surveillance, which is not before us, we are impelled to

${ }^{65}$ Id at 6.

66 See Jerome H. Skolnick, Foreword: The Sociological Tort of Defamation, 74 Cal L Rev 677, 677 (1986). Post, 74 Cal L Rev at 691-721 (cited in note 4).

${ }^{67} 682$ F2d at 6.

${ }^{88}$ Restatement (Second) of Torts $\S 568$, comment d (cited in note 9).

${ }^{68} 152$ Wis 537, $139 \mathrm{NW} 386$ (1913).

70 $139 \mathrm{NW}$ at 390. 
hold that on this ground a case was made for the jury." 11 By using the shadowing example without an explanation of the case, the Restatement failed to capture the Schultz court's concern over the intentional nature of the imputation and communication accompanying that particular case of shadowing. As cited by the JimenezNieves court, the Restatement parlays a case that emphasizes the intentional nature of the implicit communication into a general statement that any behavior that implicitly communicates an idea is a communication for purposes of defamation law. No other case law is offered for this broad definition that ignores an intent to communicate.

c) Intent as the essence of communication. In contrast, the Restatement elsewhere supports the notion that a communication must have been intended for it to be a communication at all: "To be defamatory under the rule stated in this Section, it is not necessary that the accusation or other statement be by words. It is enough that the communication is reasonably capable of being understood as charging something defamatory." ${ }^{2}$ Under defamation doctrine a defendant need not intend her communication to be defamatory. But the Restatement requires that she mean to "charge" something, to communicate something, even if she does not intend that something to be defamatory. Where shadowing is open and notorious, it charges something, and it is a communication. But not all conduct charges something. In Kennedy, for example, ${ }^{73}$ it would be absurd to argue that the anesthesia repair company's conduct in negligently repairing a machine charged anything. Only assertive conduct should be considered communication for defamation purposes.

With accident cases, the defendant's conduct causes an event. The conduct itself does not communicate an idea-people's interpretation of the accident produced by the conduct does. Under the Restatement definition of defamation, the culpable act itself "charges" something defamatory. If the culpable conduct produces some other result, which in turn damages a person's reputation, the conduct itself should not be defined as communication.

71 Id (emphasis added).

72 Restatement (Second) of Torts $\S 565$, Comment b at 170 (cited in note 9).

${ }^{73}$ See text accompanying note 27 . 
d) The Jorgensen definition of communication. The court in Jorgensen, the icy runway case, separated the defendant's conduct from the resulting accident that communicates an idea:

As we read Jimenez-Nieves, it holds that where the injury is to reputation and the conduct is the communication of an idea, the claim sounds in defamation. Thus, it is not simply the element of injury to reputation that makes conduct sound in defamation. There also must be a communication, defined as conduct that brings an idea to the perception of others.

Unlike in Jimenez-Nieves, the defendant's conduct here is not what conveyed to others the idea that caused harm to plaintiff's reputations. [Defendant's] failure to clear the runway of ice did not bring to the minds of others the concept that [plaintiffs] were not capable pilots. Rather, [defendant's] conduct caused a result-the accident-which then could have caused others to question plaintiffs' skills as pilots. . . . And without a communication, plaintiffs' claims do not sound in defamation under the reasoning of Jimenez-Nieves. ${ }^{74}$

Courts should adopt Jorgensen's reasoning and ask whether a communication was intended, without regard for whether the speaker intended that the communication be defamatory. In cases where the defendant negligently causes an accident like a plane crash, clearly no communication by word or conduct was intended. ${ }^{75}$ This test mirrors the intent to communicate element of the definition of speech discussed in United States $v O^{\prime}$ Brien $^{76}$ in the First Amendment context.

74 Jorgensen, 905 F2d at 520 (citations omitted).

${ }^{75}$ In each case where defamation preempted the field, the communication element is arguably more present than in Jorgensen, Kennedy, and Kleeblatt, where courts allowed a claim in ordinary negligence. For example, in Jimenez-Nieves, 682 F2d 1, the Social Security Administration made a typographical error in a file, stating that the plaintiff's mother had died a year later than she had. As a result, the SSA told the plaintiff's financial institutions that it was dishonoring his checks. There was arguably communication of the mistaken information by the defendant. In Ross, 551 P2d 79, the defendant CPA firm (after examining a union's books) prepared several reports that raised the question of improper use of funds by union officials. The union sued the CPA firm for negligently preparing its report; clearly, however, the report communicated defamatory matter.

${ }_{76} 391$ US 367 (1968). 
2. The Quinones approach: the plaintiff may elect her remedies.

The Quinones line of cases does not attempt to define communication. Instead, these courts hold that a plaintiff may focus on negligent conduct that is not communicative, even when communicative conduct is also present. In Quinones, the court allowed the plaintiff to recover for negligent record-keeping in spite of the resulting publication of defamatory matter by the defendant.

Similarly, in Bulkin, the court's decision turned on the plaintiff's characterization of the action. The option to choose between defamation and negligence lay with the plaintiff: "[s]ince the allegations of Bulkin's complaint are weighted toward negligent record-keeping, rather than toward wrongful publication of defamatory matter, ... . we are in accord with the rationale of Quinones and will apply its holding to our case." 77

The Jorgensen distinction between damaging reputation directly and causing an accident that causes damage to reputation is valuable, but the distinction in Quinones and Bulkin between negligent record-keeping and the defendant's conduct in publishing the results of the record-keeping is not. ${ }^{78}$ In Jorgensen, the "communication," insofar as there is one, is implicit in the accident itself, and does not come from the defendant directly. ${ }^{79}$ In the record-keeping cases, there was a communication by the defendant that was injurious to the plaintiff, but the plaintiff opted not to focus on it. The distinction allowed in Quinones and Bulkin could always apply in cases of negligent (as opposed to malicious) defamation if a complaint is properly characterized.

3. A plaintiff should not be permitted to elect her remedy.

A plaintiff can often recover for injuries under two different theories, and preemption of one by another is not an issue. For example, in a traditional defamation action where a defendant defames a plaintiff to the plaintiff's customers, the plaintiff may bring a claim for defamation or for intentional interference with contract, and may at her discretion bring one instead of the

77 Bulkin, 422 F Supp at 443.

${ }^{78}$ Two cases reject the notion that a defamation action can be recast as a negligent record-keeping action. Hamilton, 306 SE2d 340; Ross, 551 P2d 79.

${ }^{79}$ Again, this is how this case differs from Schultz, $139 \mathrm{NW} 386$, the shadowing case. In the shadowing case, the shadower was open and notorious about the act, with awareness that the act would communicate something. In Jorgensen, no communication was intended, though one occurred. 
other. ${ }^{80}$ Generally, the only prohibition is against double recovery. The Quinones and Bulkin cases accord with this general idea.

Courts must decide if there is anything particular to defamation, or to injury to reputation, that would caution against the Quinones approach of allowing recovery under another theory when a claim can sound in defamation. The justification for limiting the election of remedies may turn on the rationale behind the unique standards applied to defamation.

a) Differences between the negligence cases and defamation cases. Defamation traditionally allowed a plaintiff to recover without proof of particular damages once defamatory conduct was shown. ${ }^{81}$ Injury to reputation was thought to cause spiritual damages apart from pecuniary ones, and pecuniary ones, though real, might be difficult to prove because of remoteness. Moreover, defamation was a strict liability tort. The plaintiff did not need to show negligence; the fact that the language was defamatory would serve as proof of the defendant's malice. In order to offset the harshness of the penalty that these rules imposed on the defendant, the assertion that defamation had occurred was scrutinized carefully, with detailed standards arising out of that scrutiny. ${ }^{82}$

In the cases examined in this Comment, these concerns are not at issue. The harshness of strict liability is absent; here, by hypothesis the defendant has behaved negligently. Plaintiffs do not benefit from presumed damages. Rather, they must prove damages as with any action brought on a negligence theory.

b) Reputation claims and concerns of free expression. In New York Times Co. $v$ Sullivan, the Supreme Court constitutionalized what was always a concern in the defamation balance-society's interest in free expression..$^{83}$ Even where First

\footnotetext{
${ }^{80}$ In fact, it has been held that one remedy will not preempt another under the Federal Tort Claims Act. Rogers v United States, 397 F2d 12, 15 (4th Cir 1968).

${ }^{81}$ Rodney A. Smolla, Law of Defamation \& 9.05(1) at 9-6 to 9-7 (Clark Boardman, 1992).

82 See, for example, Keeton, Prosser and Keeton on Torts at $\S 111$ (cited in note 3).

83 376 US 254 (1964). See also Gertz v Robert Welch, Inc., 418 US 323 (1974) (public official may not recover damages for defamation related to official conduct unless actual malice is proved). For the view that free expression was always a concern in the defamation balance, see Keeton, Prosser and Keeton on Torts at \$111 (cited in note 3); Frederick Schauer, The Role of the People in First Amendment Theory, $74 \mathrm{Cal} \mathrm{L} \mathrm{Rev} \mathrm{761,} \mathrm{764-65}$ (1986) (in the 1735 pre-First Amendment trial of Peter Zenger, jury's role in libel cases was as protector of freedom of speech).
} 
Amendment rights are not abridged, allowing recovery for communications has some effect on free expression. Thus where a communication is even arguably present, a court should not disrupt the balance of the interest in reputation against the interest in free expression that has developed in the law of defamation. ${ }^{84}$

Without preemption, all defamation plaintiffs suing private individuals could circumvent defamation where actual malice is absent but where there is negligence with regard to the falsity of the publication. This would run afoul of the current purposes behind the law of defamation. For example, in Dun \& Bradstreet, Inc. $v$ Greenmoss Builders, Inc., ${ }^{86}$ the Supreme Court developed important defamation doctrine concerning recovery by a private person. The defendant credit reporting agency had published incorrect information that damaged the plaintiff's reputation for financial integrity. A high school student employed by the defendant was responsible for the record-keeping error. If the plaintiff could have brought a cause of action for negligent record-keeping despite the presence of a communication, it could have avoided a defamation action. But significantly, the court in Dun \& Bradstreet continued to voice concerns about restricting expression, though in that case it found them outweighed by the interest in reputation. Because defamation law has recognized some defendants' free expression interests even in cases of speech about private persons, claims aimed at the negligent act where a communication has also occurred, if allowed outside of defamation, would disrupt the balance the Supreme Court has deemed important.

Concern for preserving this balance of interests makes inadvisable recognition of a claim outside of defamation for damage to reputation where there is a communication by the defendant. While Sullivan and its progeny do not require this outcome, they express norms that should inform a court's view of the defamation question. Some courts have expressed vague concern over plaintiffs' attempts to circumvent defamation doctrine, but did not explain why they were so concerned. Concern over interfering with free expression provides the needed rationale.

\footnotetext{
34 The court in Quinones, 492 F2d at 1280, noted that the reason Congress excluded libel and slander from the Federal Tort Claims Act was "that government officials should not be hampered in their writing and speaking by the possibility that their actions would give rise to government liability." According to the court, "Congress focused its attention upon the type of governmental activity that might cause harm [speech], not upon the type of harm caused [injury to reputation]." Id.

8s 472 US 749 (1985).
} 
However, there are no conceivable countervailing interests when the defendants have not expressed themselves at all, either implicitly or explicitly, but have simply negligently caused an event that damaged someone else's reputation. The absence of communication removes the concern that should cause a modern court to force the claim into defamation law.

Where there is no communication, there is no conduct accurately resembling defamation. If we do not create a duty to behave with reasonable care toward the reputations of others, we fail to protect the interest in reputation, though we think it is a valuable personal asset. On the other hand, where defamatory conduct is at issue and the only bar to the claim is the statute of limitations or the Federal Tort Claims Act, a court would disrupt the balance between the interest in reputation and the protection of expression struck by current defamation doctrine. There, the defamation action is not an inadequate remedy, but the plaintiff's claim does not meet the requirements of that action.

\section{E. Summary}

So far, this Comment has shown that courts presented with negligence actions approach their cases in a number of ways. Some categorically exclude actions that are not brought in defamation. This does not seem to make sense since other actions for intentional torts are widely accepted and since reputation is a recognized interest that ought arguably to be protected from negligent conduct. Some courts will only grant actions for intentional torts. Those courts appear to use intent as a proxy for foreseeability. Though foreseeability problems should preclude many reputation claims, absence of intent should not categorically mean foreseeability cannot be shown. Finally, some courts look for a communication in the facts of the case, reasoning that if one is present, the action must be brought in defamation. Those courts disagree on the proper definition of a communication, but are correct that claims including a communication should not be cognizable as negligence actions. Defamation doctrine should be respected for attempting to strike a balance between free expression and the interest in reputation. The proper definition of a communication should be speech or conduct intended to communicate something, without regard for whether a defendant intended that the message be defamatory. 
F. A Proposed Test

The first step in addressing a case brought on a negligence theory stems from the Supreme Court's detailed attention to the protection of expression and to the balance of interests struck by the law of defamation. Courts faced with a cause of action in ordinary negligence for damage to reputation should ask at the outset whether there is any communication by the defendant associated with the harm. If the defendant intended to communicate anything by speech or conduct,-the court should find a communication for purposes of defamation (without regard to whether the defendant intended the communication to be defamatory) and force the plaintiff to state the claim in defamation, even if the defendant was otherwise negligent and even if such procedural roadblocks as the statute of limitations bar the claim. So, for example, if the complaint charges the defendant with negligent record-keeping of any kind, where that negligence led to the communication of defamatory matter by the defendant, the plaintiff should be required to characterize the case as defamation.

Cases still remain, such as Jorgensen ${ }^{86}$ and Kennedy, ${ }^{87}$ where the defendant has done nothing that remotely resembles an implicit or explicit communication. For these "accident" cases, the lack of a communication should actually preclude an action in defamation, since communication is an element of defamation. Unable to make out a cause of action in defamation, a plaintiff who attempts to recover for damage to reputation in ordinary negligence will not enjoy some of the advantages given to plaintiffs in defamation suits. Particularly with regard to proof of injury and a showing of proximate causation including foreseeability, these claims will suffer under an ordinary negligence standard. This Comment will argue that damage to reputation should be recoverable in ordinary negligence, but only when the injury was clearly foreseeable and the proof of injury is explicit. This will preclude many damage to reputation claims.

\footnotetext{
${ }^{86}$ Recall that in Jorgensen, 905 F2d 515, the defendants were responsible for a plane crash that then harmed plaintiff's' reputations as safe pilots.

${ }^{87}$ Recall that in Kennedy, $448 \mathrm{NE} 2 \mathrm{~d}$ 1332, the defendant was responsible for the death of the plaintiff's patient when the defendant negligently repaired the plaintiff's anesthesia machine. The death of the patient then harmed the dentist's reputation as a safe dentist.
} 


\section{Overview of a Reputational Negligence Action}

Even when a court decides that defamation is not the only theory for recovery, it still must decide whether negligence is an appropriate alternative theory. Courts have given almost no attention to this question. ${ }^{88}$ However, the theory of negligence is that individuals have a duty to act with reasonable care toward the persons and assets of others. The law already recognizes the value of reputation to an individual; that interest is inadequately protected against negligent behavior when no communication has occurred and therefore a defamation cause of action is not available. Extending the duty of care to reputations flows from this recognition of reputation as a important interest worthy of protection. The courts in Jorgensen, Kennedy, Oksenholt, Bulkin, Kleeblatt, and Quinones all saw the gap in protection afforded to an individual's reputation when they recognized negligence claims. Where an individual can clearly foresee specific harm to another individual's legally recognized property interest, a court can consider assigning liability to the defendant if fairness requires it.

As argued above, claims allowed on a negligence theory should be limited to those lacking a communication by the defendant. However, the following analysis of a negligence action would apply equally if a court circumvented all discussion of whether to restrict a plaintiff's ability to elect her remedies. ${ }^{89}$

\section{A. Negligence}

Typically, there are four requirements for a recovery in tort under a negligence theory: a legal duty owed by the defendant to the plaintiff, breach of the duty, proximate causation, and actual damages. Proximate causation breaks down further into three parts: but-for causation, foreseeability, and in many jurisdictions a requirement that the defendant's conduct be a substantial factor in bringing about the loss. ${ }^{90}$

8s The exception is the Jorgensen court, which decided that a negligence claim was permissible in general but not on the facts of the case. 905 F2d 515.

89 A court could reason that the interest in reputation is entitled to protection by the courts, and the method of injury to that reputation is irrelevant. Where it is reasonable to impose a duty of care to avoid physically injuring others, the extension to reputation is not. incoherent. For the reasons explained in Section III, I believe that this is inappropriate; however, the following analysis of claims under a negligence standard would apply whether all claims are allowed or only those in the absence of a communication.

90 See Keeton, Prosser and Keeton on Torts at 30 (cited in note 3); Restatement (Second) of Torts $\$ 282$ (cited in note 9 ). 
If courts permit claims in negligence, plaintiffs will face two particular difficulties. First, it will be difficult to establish that the injury was reasonably foreseeable. Second, it will be difficult to prove actual damages. One court pointed to both of these difficulties in denying recovery even though it recognized the permissibility of recovery in theory. ${ }^{91}$

Before a court imposes a duty, it requires foreseeability of harm to minimize the risk of unlimited liability. Unfortunately, as courts and commentators have pointed out, foreseeability is often as much a question of policy as it is one of fact.92 However, this Comment proposes that establishing two elements of foreseeability in the reputation cases may make it easier for a court to prevent unbounded liability. First, the injury should be to a particular foreseeable plaintiff, or a foreseeable class of plaintiffs. Second, the harm to reputation should be specifically foreseeable, and not a package of generally foreseeable damages.

This standard borrows from the reasoning of several courts in cases suggesting standards for recovery for pure economic loss. The wisdom of these economic loss decisions is that they do not impose a per se rule of nonrecovery where consequences are clearly foreseeable to a defendant, but they are extremely cautious in scrutinizing the proximate cause requirement in general and the foreseeability requirement in particular.

\section{B. Economic Loss}

Two established standards in tort law may illuminate the foreseeability factor. First, economic loss to a plaintiff that flows from property damage or bodily injury is ordinarily recoverable in an action in tort, regardless of the substantive theory of the underlying claim. ${ }^{93}$ Second, damage to "pure" economic interests, if recoverable at all, is in most jurisdictions only recoverable for intentional torts. ${ }^{94}$ The law governing pure economic interests is informative in examining negligent damage to reputation by analogy to injury personal interests in the absence of physical injury. Both damage to reputation and economic loss present the possibil-

91 Jorgensen, 905 F2d at 522-26.

${ }^{92}$ See, for example, Keeton, Prosser and Keeton on Torts at $\S 43$ (cited in note 3). Palsgraf v Long Island Rail Co., 248 NY 339, 162 NE 99, 100-01 (1928); Jorgensen, 905 F2d at 523.

${ }^{93}$ Richard A. Epstein, Charles O. Gregory, and Harry Kalvea, Jr., Cases and Materials On Torts 1335 (Little, Brown, 4th ed 1984).

${ }^{4}$ Id at 1183. 
ity of unbridled liability, both implicate difficult to ascertain damages, and both raise serious foreseeability questions.

Historically, courts have denied recovery of purely economic losses resulting from negligent acts unaccompanied by physical injury. ${ }^{95}$ Courts have argued for a manageable limit on liability with a physical harm requirement serving as a bright line cutoff. ${ }^{96}$ Courts usually see the physical consequences of negligence as limited, while indirect economic injury is unbounded. ${ }^{97}$ Courts express concerns about fraudulent claims and the potential for mass litigation and unlimited liability ${ }^{98}$ Courts also worry about the possibility of speculative jury verdicts.99

Several recent cases have extended some protection to pure economic interests. ${ }^{100}$ These courts approach the question with caution, but do not favor a presumptive denial. They argue that a defendant should be liable for all the foreseeable consequences of her negligence, regardless of how the injuries are classified. ${ }^{101}$

Courts allowing recovery of pure economic losses have stressed the foreseeability element. ${ }^{102}$ For example, in J'Aire Corporation $v$

9s See, for example, Sanco, Inc. v Ford Motor Co., 771 F2d 1081, 1086 (7th Cir 1985)(applying Indiana law); Jones \& Laughlin Steel Corp. v Johns-Manville Sales Corp., 626 F2d 280, 289 (3d Cir 1980)(applying Illinois law); Superwood Corp. v Siempelkamp Corp., 311 NW2d 159, 162 (Minn 1981).

* Restatement (Second) of Torts $\$ 766 \mathrm{C}$ (cited in note 9) (positing rule of nonrecovery, in negligence actions, for purely economic losses absent physical harm); Nebraska Innkeepers, Inc. v Pittsburgh-Des Moines Corp., 345 NW2d 124, 128-29 (Iowa 1984); Stevenson $v$ East Ohio Gas Co., 73 NE2d 200, 203-04 (Ohio App 1946). But see Kinsman Transit Company v Buffalo, 388 F2d 821, 825 n 7 (2d Cir 1968) (explicitly rejecting validity of the nonliability rule and applying flexible standard of recovery).

${ }_{97}$ The Federal No. 2, 21 F2d 313, 314 (2d Cir 1927), overruled on other grounds, Black v Red Star Towing \& Transportation Co., 860 F2d 30 (2d Cir 1988); Byrd v English, $117 \mathrm{Ga}$ 191, 43 SE 419, 420-21 (1903); Chelsea Moving \& Trucking Co. v Ross Towboat Co., 280 Mass 282, 182 NE 477, 479 (1932).

${ }^{9}$ Kinsman Transit Co., 388 F2d at 823; People Express Airlines v Consolidated Rail Corp., $100 \mathrm{NJ} 246,495$ A2d 107, 110 (1985).

"See Note, Economic Lass in Products Liability Jurisprudence, 66 Colum L Rev 917, 944 (1966) (courts express fear of indeterminate liability for merely careless defendant); Just's Inc. v Arrington Const. Co., 99 Idaho 462, 583 P2d 997, 1005 (1978); Local Joint Executive Board v Stern, 98 Nev 409, 651 P2d 637, 638 (1982).

${ }^{100}$ See, for example, Union Oil Co. $v$ Oppen, 501 F2d 558, 570-71 (9th Cir 1974) (commercial fishermen allowed to sue for recovery from defendant who negligently spilled oil into commercial waters).

${ }^{101}$ See, for example, J'Aire Corp. v Gregory, 24 Cal 3d 799, 598 P2d 60, 64 (1979); $H$. Rosenblum, Inc. v Adler, 93 NJ 324, 461 A2d 138, 153 (1983) (shareholders of company can recover against independent auditors who were negligent in preparing financial statements upon which shareholders relied).

${ }^{102}$ See, for example, Note, Purely Economic Loss: A Standard for Recovery, 73 Iowa L Rev 1181, 1194-1206 (1988); Comment, Foreseeability of Third-Party Economic Injuries-A Problem in Analysis, $20 \mathrm{U}$ Chi L Rev 283, 283-84 (1953). 
Gregory, ${ }^{103}$ the plaintiff restaurant could not open for business because the defendant contractor failed to complete work on the premises owned by a third party with whom defendant had contracted. The court allowed the action, repeatedly stressing the foreseeability of the plaintiff's economic loss to the defendant. ${ }^{104}$

\section{Foreseeability}

Foreseeability motivates the tort cases for both intentional injury to reputation and pure economic loss. In light of the significance courts place on foreseeability in these analogous types of cases, any test for recovery for negligent damage to reputation should include a strengthened foreseeability requirement. Recovery for damage to reputation raises the same concerns about limitless liability for remote consequences that plague courts in economic loss cases.

As discussed in Sections II and III of this Comment, foreseeability concerns pervade many of the cases on this issue. Some courts apply a bright line rule, allowing recovery for damage to reputation only for intentional torts, using intent as a proxy for foreseeability. One court allowed recovery in theory, but denied it on the facts of the case because of foreseeability concerns. ${ }^{105}$ Another court allowed recovery where foreseeability of the injury was assumed by law for violations of safety regulations. ${ }^{106}$ Another allowed recovery because the risk of injury had been brought explicitly to the defendant's attention in writing, which persuaded the court that the injury was foreseeable. ${ }^{107}$

\section{Foreseeable plaintiff.}

Courts should require a specifically foreseeable (and identifiable) plaintiff or class of plaintiffs, just as with economic loss cases, in order to prevent disproportionate liability from remote injuries. Several cases allowing recovery for pure economic loss articulate this stringent foreseeability requirement. In People Express Airlines $v$ Consolidated Rail Corp. ${ }^{108}$ the court described a standard for foreseeability of particular plaintiffs:

\footnotetext{
103598 P2d 60.

104 Id at 65.

${ }^{20 s}$ Jorgensen, 905 F2d at 523-24, 527.

${ }^{106}$ Oksenholt, $656 \mathrm{P} 2 \mathrm{~d}$ at 296-99.

${ }^{107}$ Quinones, $492 \mathrm{~F} 2 \mathrm{~d}$ at 1277.

108495 A2d 107.
} 
[a]n identifiable class of plaintiffs must be particularly foreseeable in terms of the type of persons or entities comprising the class, the certainty or predictability of their presence, the approximate numbers of those in the class, as well as the type of economic expectations disrupted. ${ }^{108}$

Similarly, in J'Aire Corp. $v$ Gregory, the court found that the defendant had intended his performance to affect the plaintiff, who was therefore directly foreseeable. ${ }^{110}$

So, for example, the anesthesia repair company can anticipate that if a patient is killed by its anesthesia machine, the reputation of the dentist who administered the anesthesia will suffer. The repair company might not be expected to foresee, however, that the reputation of the insurance company that refers patients to that particular dentist might suffer as well. Although but-for causation may still be present with respect to the insurance company, that plaintiff is not readily foreseeable. Similarly, a pharmaceutical corporation can foresee damage to the reputations of physicians prescribing a drug if that drug is mislabelled; however, it may not be expected to foresee damage to the reputation of referring physicians. These are judgments of degree, not kind, that judges typically must make in negligence actions. The difference here is only that courts should be particularly strict in their review of this question, as many are in economic loss cases.

\section{Foreseeable harm.}

When a court cannot be reasonably certain that a defendant could foresee the particular injury to reputation that would result, it should not allow recovery. This rule is tailored to avoid the disproportionate effect that assessing liability would have in light of remote foreseeability. Courts can thereby provide recovery in the interest of fairness while placing limits on frivolous or speculative claims.

A runway maintenance crew may be able to foresee various physical and emotional injuries that could result from the negligent performance of its duties. However, whether it may reasonably contemplate specific damage to the pilots' reputations is a more difficult question. A court should be careful to ascertain what exact injuries the defendant could be expected to foresee in analyzing these cases. However, the anesthesia repair company, recogniz-

\footnotetext{
109 Id (citations omitted).

$110598 \mathrm{P} 2 \mathrm{~d}$ at 63-64.
} 
ing that a negligently repaired anesthesia machine could cause drastic physical harm, might also directly anticipate the damage the dentist's reputation would suffer from the death of a patient. Moreover, where a harm is explicitly stated in advance, as where a warning of the risk is published in an employee procedures manual, foreseeability is established. The foreseeable harm requirement may be difficult to apply because it is another question of degree. However, it is preferable to a per se rule against recovery for damage to reputation where recovery would be in the interest of fairness in some situations. Courts have been willing to overcome the difficulty of applying the requirement of foreseeable harm in economic loss cases in the interest of fairness, ${ }^{111}$ thus lending support to the practicality of the solution.

\section{Misplaced Blame}

One unique element links most of the cases where recovery is appropriate: the plaintiff is mistakenly held responsible for the defendant's negligent act. The plaintiff's reputation is injured because people assume that the precise consequence of the defendant's negligent act is the plaintiff's fault. Courts could use this distinguishing feature in addressing the foreseeability question. A court would ask whether the defendant could foresee that one consequence of her negligent act would be a mistaken public perception about fault. So, for example, the dentist is believed to be responsible for the death of his patient, which was actually the fault of the anesthesia repair company. This imputation to the dentist is reasonably foreseeable to the repair company. The prescribing physician is believed to be responsible for the blinding of his patient, despite the fact that the pharmaceutical company is in fact responsible for that injury. And the pilots are believed to be responsible for the plane crash, though fault has been established in the maintenance crew. Quinones provides a contrary example. As a result of negligent record-keeping, the plaintiff's reputation suffers, but only because a communication results from the record-keeping. The plaintiff is not suffering because she is thought by others to have kept the records negligently herself; she is not thought to be a poor bookkeeper.

In general, the defendant may be asked to foresee that the person who appears to be the closest to the accident, whose negli-

111 J'Aire, 598 P2d at 63; Clay v City of Jersey City, 74 NJ Super 490, 181 A2d 545, 551 (1962), aff'd, 84 NJ Super 9, 200 A2d 787 (1964). 
gence people would first suspect, will suffer reputational damages as a result of an accident. Therefore, the plaintiff's close proximity to the accident is a first cut at the foreseeability of harm as well as the foreseeability of the particular plaintiff.

\section{E. Proof of Damages}

In defamation law, a tortured set of rules has developed to deal with the difficulty of proving damage to reputation. ${ }^{112}$ The most obvious mechanism is presumed damages. This device allows an award of damages without any proof whatsoever of actual injury or damage. ${ }^{113}$ Presumed damages may be available when actual malice is established, ${ }^{114}$ or when the case involves a private-figure plaintiff on a matter of no public concern. ${ }^{116}$ Two other types of damages exist-special damages, which are pecuniary, and actual damages, which are non-pecuniary damages supported by evidence. There is no role for presumed damages in an ordinary negligence action because proof of damages is a primary element in a negligence claim. In this respect, damages to reputation in ordinary negligence are more difficult to recover than in an action in defamation. Both special damages and actual damages, however, should be recoverable in ordinary negligence under the strict foreseeability test outlined above.

In defamation, damages to pecuniary interests are called special damages. In ordinary negligence, they are called economic loss. In an ordinary negligence action, they should be subject to the developing law dealing with economic loss. This Comment's proposed test is consistent with the law of economic loss-thus its standards

112 Reputation is an odd concept. It could be viewed as the aggregation of a number of ways a person can suffer harm, though it is sometimes described as a discrete piece of personal property, itself susceptible to injury. "Actual damages" do not seem present when the reputation itself is injured, but instead when tangible economic or noneconomic losses flow from the injury. In other words, in proving actual damage to reputation, a plaintiff finds herself proving that certain relationships in her life were injured. She is compensated according to the harm to each of the relationships. In addition, she is compensated for economic losses resulting from the defendant's negligent behavior. In a negligence action, perhaps the most coherent solution would be to allow recovery for each of the discrete injuries, without calling it damage to reputation. In effect, the test proposed does that. This would not apply equally to the law of defamation, since presumed damages are still available in certain cases.

113 Belli v Orlando Daily Newspapers, 389 F2d 579, 582 (5th Cir 1967); Dalton v Meister, 52 Wis 2d 173, 188 NW2d 494, 497 (1971); Charles T. McCormick, The Measure of Damages for Defamation, 12 NC L Rev 120, 127 (1934); David A. Anderson, Reputation, Compensation, and Proof, 25 Wm \& Mary L Rev 747, 748 (1984).

11 Gertz, 418 US at 350 .

${ }^{116}$ Dun \& Bradstreet, 472 US at 761-63. 
do not create a conflict. ${ }^{116}$ Since actual pecuniary losses must be shown, there is no opportunity to circumvent the requirement of showing damages by characterizing economic loss as damage to reputation.

The standards for proving actual damages in defamation law are adequate to demonstrate damage to reputation in ordinary negligence, given a generally recognized legal interest in reputation. ${ }^{117}$ Actual damages are designed to compensate for injury to "relational interests." 118 Actual harm need not be pecuniary. Evidence of humiliation or anguish, including the plaintiff's testimony alone, can be sufficient proof of actual harm. ${ }^{119}$ Evidence sufficient to show these kinds of "actual damages" in a defamation action under state law should apply to proof of the same damages in ordinary negligence. Standards in a given state for showing emotional distress should apply when emotional distress is claimed as part of the actual damage from the injury to reputation. ${ }^{120}$ Since evidence is already required in many defamation cases, proof of damages in ordinary negligence will only differ from defamation in that presumed damages will never be available.

\section{CoNCLUSION}

Modern defamation doctrine reflects a careful balancing of the interest in reputation and the interest in expression. Accordingly, when a complaint for damage to reputation involves any communication by the defendant, the plaintiff should be constrained by the standards set out in the law of defamation. A court should identify a communication by asking whether the defendant, by conduct or speech, intended to communicate something. This inquiry should not take account of whether the defendant intended that the communication defame the plaintiff. If the complaint focuses on negli-

116 If a court adopted a different standard of recovery than the one proposed in Section IV, the special damage issue might present a problem. If a court wishes recovery for special damages to be more readily available than for economic loss, the emerging law with respect to economic loss will be disrupted; economic loss and special damages are conceptually the same thing, in different areas, so parity must be maintained.

117 For a description of the different ways of viewing actual damages, see Anderson, 25 Wm \& Mary L Rev at 747 (cited in note 113 ).

11 Smolla, Law of Defamation \$ 9.06[6] at 9-14 to 9-15 (cited in note 81).

119 Time, Inc. $v$ Firestone, 424 US 448, 460 (1976).

120 It should be noted, though, that this damage must be for emotional distress due to injury to the plaintiff's reputation. So, for example, in Kennedy, $448 \mathrm{NE2d}$ at 1332, the dentist should not be able to recover for emotional distress caused by witnessing the death of his patient; this is unrelated to his reputational damage and prohibited by the rule which restricts such recovery to family members only. 
gent conduct, where after the negligent act the defendant communicated the defamatory information herself, a court should not allow a negligence claim. Once a court has decided that defamation does not preclude a negligence action, a plaintiff should be able to protect her interest in reputation in an ordinary negligence action, provided she has shown two elements in particular. First, she must show particular foreseeability-both that the plaintiff or class of plaintiffs was foreseeable, and that the harm to the plaintiff's reputation was clearly foreseeable. As a proxy for foreseeability, the court may ask whether the plaintiff suffered injury by being blamed for the defendant's negligent act. Second, she must prove her damages to reputation in their entirety, either by showing lost contracts or job opportunities, or evidence of emotional distress as a result of reputational damage. This standard should allow for recovery in cases where justice warrants it, but should curb unreasonable suits. 
, 